\title{
A KÜLFÖLDI TŐKE SZEREPE ÉS TÉRBELI TERJEDÉSE MAGYARORSZÁGON
}

\author{
(The role and spatial spreading of foreign capital in Hungary)
}

\section{NAGY GÁBOR}

A külfơldi tőkebefektetések Magyarország számára a gazdasági megújulás egyik legfontosabb eszközét jelentik: nem hiteljellegü tökeforrást a beruházásokhoz, technikai megújulást, technológia-transzfert, új szervezési-vezetési módszereket, piaci kapcsolatokat. Megjelenésük egy adott térség számára a felzárkózás esélyét biztosíthatja.

Számunkra a feladat megfogalmazásakor nem elsősorban a befektetett tőke nagysága volt a kérdés, inkább ennek térbeli eloszlása, terjedése a telepúléshálózatban. A tanulmányban igyekeztünk a rendelkezésre álló adatokból összehasonlítható, az egész vizsgált korszakon végigvezethető adatbázist szerkeszteni, s ezekböl megalapozott következtetéseket levonni. Következtetéseink ellenörzésére felhasználtuk az esettanulmányokat, a szakirodalmat és saját e témában végzett felméréseinket.

\section{A jogi szabályozás változásai, a vizsgált korszak szakaszolása}

A külföldi müködőtöke-beruházások jogi feltételeit 1972-ben teremtettük meg, de e lehetőséget egészen a nyolcvanas évek elejéig alig használták ki, hiszen a nemzetközi pénzpiacokon az ország olcsó hitelekhez jutott. 1980-ig mindössze nyolc vegyes vállalat müködését hagyták jóvá egyedi engedélyezéssel. A múködőtőke-bevonás lehetőségének erỏteljesebb kihasználását fékezte a COCOM-lista, mely megfosztotta az országot a legmodernebb technológiák beáramlásának lehetőségétől.

A 63/1982. számú pénzügyminisztériumi rendelet lehetỏvé tette off-shore cégek és vámszabadterületi társaságok alapítását (Páll Gy, 1993). Az előnyösebb feltételek mellett sem alakultak nagy számban vegyes vállalatok, 1987 végén számuk mintegy 130-ra volt tehető. A kezdódő beruházási hullám a következő évvel indult, amikor egy év leforgása alatt legalább megduplázódott e cégek száma. Mindezzel együtt az 1972-1988 közötti időszakot egységként kezeltük, $\mathrm{s}$ azt a későbbi folyamatok elózményének tekintettük.

Még 1988-ban megszuletett több olyan sarkalatos gazdasági törvény, mely azóta is meghatározza a vállalkozások és azon belül a kulföldi tỏke müködésének kereteit. Időben elsö a társasági törvény (1988. VI. évi tv.), mely a vegyes vállalatok jogi kereteit jelölte ki. Az 1988. évi XXIV. törvény a külföldiek magyarországi befektetéseinek általános sza- 
bályozását biztosította. 1989. július 1-jén lépett életbe az átalakulási tơrvény, mely lehetővé tette az állami vállalatok gazdasági társasággá alakulását, megkönnyítve számukra a külföldi tỏke fogadását (Páll Gy. 1993).

A szabályozás legfontosabb elemei:

- a külfóldi tag konvertibilis készpénz-hozzájárulása devizában tartható a vállalat bankszámláján, abból importengedély nélkül szerezhetök be termelőeszközök és alkatrészek;

- a külföldi fél a nyereséget konvertibilis devizában szabadon utalhatja haza;

- az apportként behozott termelöeszközöket nem terheli vám;

- alapitható 100\%-ban külföldi tulajdonú cég is;

- külföldi és hazai magánszemélyek egyuitt is alapithatnak társaságot;

- a vegyes vállalatok mentesülnek a bér- és árszabályozás alól;

- a megalakult vegyes vállalatok jelentős adókedvezményben részesültek.

Ez a liberális törvényi szabályozás széles körben lehetővé teszi a külföldi tőke részvételét a hazai gazdaságban, annak megújitásában. A kormányzat a remélt modernizáció érdekében hajlandó volt jelentős bevételekrỏl lemondani. A liberális szabályozás hatását némileg lerontotta a még meglévő hosszadalmas engedélyezési eljárás, mely a bejegyzéseket megelözte.

Az 1989-es év végére már közel 1600 vegyes vállalatot tartottak nyilván, mely minőségi ugrást jelentett a korábbi állapothoz képest (Balázsné Varga M. 1991, Meskó A. 1992). Ezért ezt az évet ,fordulópont"-ként értékeljük a külföldi tőke hazai megjelenésében.

1990-91-et a "nekilendülés" éveinek nevezhetjük, hiszen évröl évre több vegyes vállalatot alapítottak, $s$ minden évben az előzőnél nagyobb volt a tỏkebeáramlás volumene. Ebben a két évben a hazai gazdaság szereplöinek száma több mint háromszorosára, a vegyes vállalatok száma hétszeresére növekedett (Diczházi B. 1993). A tömeges megjelenés hatására elindult egy területi kiegyenlítődési folyamat a nagyrégiók, illetve a megyék szintjén, s hasonló folyamatok zajlottak le a településhierarchia egyes szintjein.

$\mathrm{Az}$ alapítások lendületét csökkentette az 1990. szeptember 1-jén életbe lépö privatizációs törvény, mely új csatornát nyitott a befektetni szándékozó külföldi tőkéseknek (Páll J. 1993). A szakasz lezárását a vegyes vállalatoknak nyújtott kedvezmények mérséklése jelentette (1991. évi LXXXV. tv.) A törvény egyrészt tovább pontosította a vegyes vállalatokra vonatkozó rendelkezéseket, valamint szigorította a korábbi kedvezmények megszerzésének feltételeit, az igénybevehetőség lehetséges időtartamát. Megemelték az adókedvezményhez szükséges minimális alapitói vagyon mértékét a célból, hogy ösztönözzék a nagyobb méretú vállalkozások alapítását és kiszűrjék a „kalandortökét”. A törvény 1993. december 31 -ét határozta meg végső idöpontként, ameddig a külföldi részvételủ gazdasági társaságok adókedvezményre való jogosultságát meg lehetett szerezni.

A törvényi szabályozás csak korlátozott eredményeket hozott. Nem növekedett az egy cégre jutó alapítói töke nagysága, $\mathrm{s}$ ezzel egyidejüleg a befolyó töke összvolumene is stagnált, illetve csökkent. Az a folyamat, mely az 1990-91-es éveket jellemezte - azaz a 
vegyes vállalatok számának ugrásszerü növekedése, a befektetett tőke lassú dekoncentrációja - 1992-töl lezárult. Újra megfigyelhetö a befektetések erősödó területi koncentrációja, elsősorban a föváros és környékének dominanciájával. Az 1992-93-as éveket ismét önálló szakasznak értelmeztük, melyet a „csúcspont és telítódés" fogalmával jellemeztünk.

Megítélésünk szerint 1994-től megint új szakasz kezdődik a vegyes vállalat alapításokban, melynek jellemzöit részletes kutatásnak kellene feltárnia.

\section{Az ágazati megoszlás és a társasági forma változásai}

Az 1988-ig alapított vegyes vállalatok 63\%-a az iparban alakult (1. táblázat), $\mathrm{s}$ az addig behozott össztőke 55\%-a már oda koncentrálódott. A folyamat csak az utolsó két évben változott meg ebbe az irányba, hiszen 1986-ig a legnagyobb befektetések a pénzügyi szférában jelentek meg: Közép-Európai Nemzetközi Bank, Citybank Budapest, InterEurópa Bank, Unicbank. Ezeknek az alapitásoknak köszönhetően 1986-ra a behozott tőke hozzávetőleg kétharmadát a pénzügyi szféra vette fel. Általában igaz erre a korszakra, hogy minden egyes vegyes vállalat megalakulását hosszantartó, magas állami szinten folyó tárgyalások elóztek meg, ahol a legfontosabb tényezö a személyes kapcsolatok rendszere volt (Klekner P. 1990).

\section{TÁBLÁZAT}

A vegyes vállalatok ágazati megoszlása 1989-1993 között (\%)

(Sectoral breakdown of the joint ventures in 1989-1993 [\%])

\begin{tabular}{|l|r|r|r|r|r|r|r|}
\hline Ágazat & 1988 & 1989 & 1989 & 1990 & 1991 & 1992 & 1993 \\
\hline Mezögazdaság & 0.9 & 1.5 & 1,5 & 1,5 & 1,5 & 1,4 & 1,3 \\
Ipar & 63 & 38,6 & 33,8 & 30,1 & 23,9 & 18,5 & 19,7 \\
Épitóipar & n.a. & n.a. & 9,4 & 8,4 & 6,6 & 5,1 & 4,4 \\
Fejlesztés & 11,0 & 7,0 & n.a. & n.a. & n.a. & n.a. & n.a. \\
Kereskedelem & n.a. & n.a. & 33,1 & 36,7 & 45,4 & 52,3 & 51,5 \\
Szállítás-hírközlés & n.a. & n.a. & 2,5 & 2,3 & 3,2 & 3,5 & 4,2 \\
Egyéb anyagi szolgáltatás & n.a. & n.a. & 14,7 & 14,8 & 14,3 & 14,8 & 15,3 \\
Nem anyagi szolgáltatás & n.a. & n.a. & 5,5 & 6,2 & 5,1 & 4,4 & 3,6 \\
Tercier-kvaterner & 25,1 & 52,9 & 55,8 & 60,0 & 68,00 & 75,0 & 74,6 \\
\hline Összesen & 100,0 & 100,0 & 100,0 & 100,0 & 100,0 & 100,0 & 100,0 \\
\hline
\end{tabular}

Megjegyzés: n.a. - nincs adat

Forrás: 1988-1989 Klekner P. (1990); 1989-1990 Balázsné Vaga M. (1991); 1991 I ván L. (1993); 1992-1993 Tájékoztató..., 1992 
1988-ra az ipar dominanciája jellemezte a vegyes vállalatok ágazati szerkezetét, melyen belül a legfontosabb ágazat a gépipar lett (az ipari alapítások $42 \%$-a, illetve az iparba áramló töke $29 \%$-a). A vegyes vállalatok számát tekintve fontos szerepe volt a könnyüipari, a befektetett tỏke nagyságát tekintve pedig az épitőanyag-ipari vállalkozásoknak. A szolgáltatások - elsősorban a pénzügyi szféra révén - a befektetett tőkébỏl 27 , a kereskedelem 16\%-kal részesedett (ez utóbbi ekkor még szinte kizárólag belkereskedelmi tevékenységet jelent), míg a mezőgazdaság szerepe marginális maradt (Klekner P. 1990).

A társasági formában a kft. dominált, a vállalkozások közel $90 \%$-a választotta ezt a formát, bár az alaptőke átlagos nagysága messze meghaladta a minimálisan szükséges egymillió forintot (2. táblázat).

\section{TÁBLÁZAT}

$A$ vegyes vállalatok megoszlása társasági forma szerint (db)

(Breakdown of the joint ventures by corporate form [in numbers])

\begin{tabular}{|l|r|r|r|r|r|r|}
\hline Gazdasági forma & 1988 & 1989 & 1990 & 1991 & 1992 & $\begin{array}{r}1993 \\
\text { vidék }\end{array}$ \\
\hline Rt. & 33 & 130 & 297 & 421 & 517 & 19 \\
Kft. & 235 & 1430 & 5351 & 10701 & 13036 & 1299 \\
Bt. & n.a. & n.a. & n.a. & n.a. & 3306 & 88 \\
Kkt. & n.a. & n.a. & n.a. & n.a. & 108 & 1302 \\
Egyéb & 9 & 30 & 45 & 213 & 117 & 6 \\
\hline Összesen & 277 & 1590 & 5693 & 11335 & 17182 & 2714 \\
\hline
\end{tabular}

Megjegyzés: n.a. - nincs adat

Forrás: 1988-1989 Balázsné Varga M. (1991); 1990-1991 Iván L. (1993); 1992. Tájékoztató..., (1992); 1993 saját számítás.

1989 végére a vegyes vállalatok száma már meghaladta a másfél ezret, mellyel összesen félmilliárd dollárnyi külföldi tőke áramlott be az országba (Balázsné Varga M. 1991). A cégek számának gyarapodása együtt járt az alapítói tőke átlagos nagyságának csökkenésével, mivel számos közepes és kis méretủ külföldi társaság is megjelent befektetöként, partnerként. Ezzel párhuzamosan a cégek legnagyobb árbevételt produkáló egyötöde a konvertibilis vagyon $85 \%$-ánál is nagyobb részesedéssel rendelkezett.

$\mathrm{Az}$ újonnan alakult vegyes vállalatok ágazati szerkezete lényegesen átalakult az elóző időszakhoz képest. A gépipar kivételével minden ipari ágazat súlya csökkent. A korábbi négy vezetơ ág (gépipar, épitőanyag-ipar, vegyipar, könnyüipar) részesedése a vegyes vállalatok számából 53\%-ról 28\%-ra mérséklödött, s a befektetett töke egyharmada koncentrálódott ide, szemben az egy évvel korábbi 50\%-os aránnyal.

Az ipar visszaszorulásával párhuzamosan megindult a szolgáltató - ezen belül is elsősorban a kereskedelmi - vállalkozások számának gyors növekedése. (Az 1989-ben alapított vegyes vállalatok $40 \%$-a kereskedelmi volt.) A megerősödö tercier ágazat elsősorban 
a kisebb befektetöket vonzotta, amelyek célja az adókedvezmények megszerzése és a gyors megtérülés volt. A tőkeimport fele már a szolgáltatások valamelyik ágazatában talált helyet magának (1. táblázat).

A változások ellenére még mindig az iparban müködött a legtöbb külföldi érdekeltségü vállalkozás, $\mathrm{s}$ itt koncentrálódott a befektetett töke nagyobb része is, de a nemzetgazdasági ágak közül a pénzügy-biztosítási szférában, illetve a szállitás-hírközlési ágazatban is számottevő tőke jelent meg. A társasági formák közül továbbra is messze a legnépszerübbnek a kft. bizonyult, az összes társaság 90\%-a idetartozott (2. táblázat). Négyszeresére nőtt egy év alatt a részvénytársaságok száma, ezek mind nagyobb alaptőkével jöttek létre, s forgalmuk alapján is a nagyvállalkozók közé tartoztak. Az egyéb formák közül a még meglévő közös vállalatok száma volt a legnagyobb (12db).

A magyarországi vegyes vállalatokba befektetett külföldi tóke nagysága 1990 végén elérte az 1,2 milliárd dolláros nagyságrendet (Iván L. 1993), majd újabb egy év elteltével az összeg több mint megduplázódott.

Az ipar továbbra is elsősorban a nagybefektetőket vonzotta. 1990 végére a 25 legnagyobb ipari vegyes vállalat összes befektetései meghaladták a 0,3 milliárd dollárt. (E 25 cégból 17-et az évben alapítottak.) Az egymillió dollár feletti külföldi tökerésszel rendelkező ipari vegyes vállalatok koncentrálták az ágazat konvertibilis vagyonának $80 \%$-át, miközben számarányuk mindőssze 7\%-ot tett ki (Balázsné Varga M. 1991).

$\mathrm{Az}$ építöipar megnövekedett vonzerejét a fövárosban megindult szálloda- és irodaház épitkezéseknek köszönhette (1. táblázat). A mezögazdaság jelentősége továbbra is periférikus, a kủlföldi töke beáramlása e területen minimális.

Legnagyobb számban a kereskedelmi ágazatban tevékenykednek vegyes vállalatok, arányuk 1990 végére meghaladta az összes cég 40\%-át (1800 vállalkozás). Az ágazatba befektetett töke mennyisége is növekedett, bár megoszlása egyenlötlenebbé vált.

A szolgáltatási profilú vegyes vállalatok száma 1990-ben lényegesen gyarapodott, számuk túlhaladta a hatszázat, ám arányuk ezzel egyưtt valamelyest csökkent. A tókeállomány legnagyobb ütemü gyarapodása a pénzügy-biztositási szférában történt. Lassan gyarapodott a nem anyagi szolgáltatások társaságainak száma is, bár alapitói vagyonuk továbbra is minimális maradt.

A vegyes vállalatok ágazati megoszlásában 1991-ben a megelöző időszak tendenciái folytatódtak, ám lassuló ütemben (Iván $L$. 1993). Tovább növekedett a kereskedelmi ágazat súlya (az év végére a vállalkozások fele müködött ebben a szférában) és tovább mérséklödött az iparé, a cégek $24 \%$-a tartozott valamely ágazatához. A befektetett külföldi tỏke 56\%-a viszont továbbra is az iparba áramlott (legnagyobb fogadó ágazatai az élelmiszeripar és a gépipar voltak), ugyanekkor a kereskedelemben a beérkezett tôke egyhatoda jelent meg. A szolgáltatások közül különlegesen vonzó területnek bizonyultak a pénzügyekkel, ingatlanokkal, bérbeadással és különböző gazdasági jellegủ szolgáltatásokkal kapcsolatos alágazatok, melyek együttesen a vegyes vállalatok egyötödét koncentrálták (Magazin Kiadó, 1993). 
A korábbi évekhez viszonyítva további változást jelent a nem anyagi szolgáltatások részarányának növekedése, a szolgáltatásban tevékenykedỏ cégek $21,3 \%$-a volt idesorolható. A társasági forma választásában ebben a szakaszban nem voltak lényeges súlyponteltolódások, ám néhány tendenciát ki kell emeleni (2. táblázat). A legszembetúnöbb, hogy meredeken növekedett a minimális alaptökével létrejött kft.-k száma és aránya. Az 1990-ben alapított cégeknek 57\%-a a minimális alaptőkével létrehozott kft. volt, s ez az arány 1991-ben tovább növekedett, megközelítve az alapított vegyes vállalatok számának kétharmadát.

A cégek átlagos méretének csökkenésében szerepet játszhatott az is, hogy míg 1989 előtt a hatóságok általában nem engedélyezték a kis alaptőkéjü, kereskedelmi vagy szolgáltató szektorban müködő társaságok alapítását, addig ez a bürokratikus akadály 1990töl megszünt.

A legtőkeerỏsebb cégek legnagyobb számban továbbra is a részvénytársasági formát választották, ezeknek száma 1991 végére meghaladta a négyszázat. Egyéb társasági formában (szövetkezet, kisszövetkezet, gmk., pjt., bt., kkt., közös vállalat stb.) mindössze 213 cég müködött. $\mathrm{E}$ formák közül a betéti társaság vált a legnépszerübbé, hiszen itt nincs meghatározva a minimális alaptöke nagysága. A betéti társaság első tömeges megjelenése a jugoszláv utódállamokból érkezỏ befektetökhöz kapcsolható, akiknek sok esetben a szukséges tökéje sem lett volna meg komolyabb cég megalapításához.

Az ágazati megoszlást tekintve az 1992-1993-as szakaszban az erővonalak markáns újjárendeződése nem következett be, csupán kisebb mozgások zajlottak le az egyes ágazatok között (Meskó A. 1994). Az ipar aránya a befektetett tőkéből 1992 végére $48,4 \%$-ra csökkent, s e szektorban tevékenykedỏ cégek számaránya is $20 \%$ alá esett (Tájékoztató..., 1993). Ugyanakkor a gazdaság szektorai közül ekkor még mindig az iparban alakultak a nagyszervezetek. Az alapítói vagyon átlagos ágazati maximuma a villamosenergia-iparhoz köthetö, 0,8 milliárd forinttal cégenként.

A kereskedelem részesedése a befektetett külföldi tökéböl lassú növekedést mutat, mértéke 1992 végére meghaladta a 14\%-ot.

A szolgáltatások közül figyelemre méltó a pénzügyi és kapcsolódó tevékenységek visszaszorulása. Vélhetöen 1991-ig megjelentek azok a nyugati pénzügyi szervezetek, melyek már a rendszerváltás óta jelen akartak lenni a kelet-európai piacokon, így új szereplök megjelenésére a bankprivatizáció megindulásával számíthatunk, illetve a nyugati határon a kisebb osztrák pénzintézetek benyomulása jelenthet változást a pillanatnyi állapothoz képest.

Hazánkban folyamatosan és igen gyors ütemben növekedett a gazdaság szereplöinek a száma, ezzel párhuzamosan emelkedett mindenféle gazdasági tevékenységet segítỏ szolgáltatás iránt a kereslet. A gazdasági szolgáltató ágazatokban müködö vegyes vállalatok jelentősége 1992 végére (az itt koncentrálódó deviza befektetéseket tekintve) megközelítette a pénzügyi szféráét, az alapitások számát tekintve pedig stabilan a harmadik helyet foglalta el a kereskedelem és az ipar mögött. 
A társasági formák közül 1992 végén még mindig a kft.-k aránya a legmagasabb (az összes vegyes vállalat háromnegyede) (2. táblázat). A teljes befektetett külföldi töke csaknem 60\%-a a kft.-kben múködött. A részvénytársaságok száma meghaladta a félezret, aránya elérte a 3\%-ot, ugyanekkor az összes külföldi befektetés 36\%-át e társaságok koncentrálták.

Új jelenség a nem jogi személyiségu gazdasági társaságok tömeges megjelenése a vegyes vállalatok között, ezek közül is kiemelhető a betéti társaságok robbanásszerü gyarapodása. Számuk az év végére meghaladta a 3300-at, ám szerény átlagos méretúkre utal, hogy az összes külföldi tỏke mindössze $2 \%$-át tömörítették.

A társasági formák választásában elóször tapasztaltunk lényeges területi különbségeket. A nem jogi személyiségú társaságok a déli határ menti megyékre, azoknak is a déli területeire koncentrálódnak, azaz Csongrád, Bács-Kiskun megye a legnagyobb fogadóterủletek, de Békés és Baranya határmenti településein is szép számmal találunk bt.-ket és kkt.-kat. Az év második felétöl a Romániából érkezö tőke is egyre nagyobb számban választja a nem jogi személyiségủ formákat, ezt elsősorban Békés és Csongrád megye keleti peremén figyelhettiuk meg.

Az 1993-as alapitásokból a vidéki székhellyel bejegyzett társaságokról létezik a legteljesebb adatbázisunk, így elemzésünk is ezekre koncentrálódik. A vegyes vállalatok csaknem felét a kereskedelmi ágazatban hozták létre, de a jegyzett tőkének csak 12-13\%-át fogadta az ágazat (Cégközlöny, 1993). Továbbra is dominálnak a kis alaptökével létrehozott társaságok. A gazdasági tevékenységet segítő szolgáltatásokban a vállalkozás alapítások gyors üteme 1993-ra is jellemzö maradt, több mint 130 szervezet alakult, összesen közel 0,6 milliárd forintos alaptőkével. Elsősorban a regionális központokban, de még ott is csak minimális számban és csekély tőkeerővel jelentek meg a pénzügy-biztositási szféra vállalkozásai, s hasonló jellemzóket találunk a nem anyagi szolgáltatások terjedésében. A legnagyobb tőkeerővel rendelkező befektetések a feldolgozóiparban tömörültek, ezen belül 1993-ban a gépipar, a vegyipar és a kohászat volt a legjelentősebb befektetési terület.

A társasági formában megmutatkozó éles területi különbségek valamelyest mérséklödtek, mert az osztrák, illetve német kisbefektetök is felfedezték maguknak a nem jogi személyiségú formákban rejló lehetỏségeket, s április-májustól kezdve egyre nagyobb számban alapítottak bt.-ket.

Tulajdonképpen a vegyes vállalatok esetében csak az országos vállalkozás alakulások társasági forma választásában bekövetkezett változásokat láthatjuk viszont, bár a nem jogi személyiségú társaságok elterjedtsége a hazai tulajdonú szervezeteknél arányaiban nagyobb. A nem jogi személyiségü formák nagyarányú megjelenését ezek közül is leginkább Csongrád megye déli része - Szeged és környéke - mutatja, ahol a kft.-k és az rt.-k egyiuttes aránya alig haladja meg a 20\%-ot. Ezzel ellentétben a jogi személyiségü formák túlsúlya jellemzi az észak-dunántúli és az észak-magyarországi megyéket (bár az 1994-es részleges adatok szerint elöbbiekben a jogi személyiségü cégek aránya valamelyest csökkent.) 


\section{A külföldi töke származási országai, a külföldi tőkerészesedés változása a vegyes vállalatokban}

1988 végéig 23 országból érkezett hozzánk számottevő tőkeállomány (Klekner P. 1990). A legtöbb vegyes vállalatot osztrák tókével alapították, s Ausztriából érkezett a legnagyobb volumenü tőke is. A cégek számában az akkori NSZK a második helyen álit. A nagyobb számú alapításoknál kiemelhetó Svájc és az USA, mely utóbbiból érkezett a második legnagyobb tőkeállomány. A jelentős befektetők között szerepel még Olaszország, Japán, Luxemburg, Hollandia és a Szovjetunió (3. táblázat).

A befektetéseknél az átlagos külföldi tulajdonrész ágazatonként eltérö képet mutat. $\mathrm{Az}$ iparban a legtöbb vegyes vállalat a fele-fele arányhoz közeli részvétellel alakult, erre utal a 47\%-os átlagos külföldi tulajdonrész is (Klekner P. 1990). (Ekkor az engedélyezési eljárásoknál preferálták a minimális hazai többséggel alakuló társaságokat, s inkább csak megtủrték a külföldi többséggel alakult szervezeteket. Más kérdés, hogy a tökeemelések során a belső tulajdoni arányok gyakran a külföldi tulajdonostárs javára változtak, de ennek követésére országos megbízható adatforrások hiján nem vállalkozhattunk.)

A külföldi tökerész a pénzügy-biztosítási szférának köszönhetően a szolgáltatási ágak átlagában volt a legmagasabb, itt közelítette az 53\%-ot, míg az eddig nem említett ágazatokban $43-45 \%$ között ingadozott.

1989 végén már 38 ország befektetöi voltak jelen a magyarországi vegyes vállalatokban (Balázsné Varga M. 1991), ezek közül mindössze négy képviselte az akkor még létező KGST-t, s az innen érkezó tökeimport 96\%-a a Szovjetunióból származott (mellette Csehszlovákia, Lengyelország és az NDK befektetói voltak még jelen).

Az átlagos kủlföldi tỏkerészesedés az egy évvel korábbihoz viszonyítva jelentösen csökkent (47,4\%-ról 34,4\%-ra), ami együttjárt az egy vegyes vállalatra jutó külföldi tőke nagyságának erőteljes csökkenésével (Balázsné Varga M. 1991). A nagyobb árbevételủ cégeknél az alapítói vagyonban az átlagosnál is kisebb volt a konvertibilis tőkerész, országosan nem érte el a 30 százalékot.

Egy 1990 végén lezajlott - 1150 vegyes vállalatot érintő - felmérés szerint hazánknak 47 országgal volt tóke-behozatali kapcsolata (Iván L. 1993). Számszerüleg közel ezerezer vegyes vállalati részvétellel az alapítók sorát Ausztria és az NSZK vezette, s e két ország adta a kapcsolatok 52\%-át. Figyelemre méltó a két délnémet tartomány, Bajorország és Baden-Württemberg aktivitása, hiszen ez év végéig innen származott a németországi befektetések háromnegyede (3. táblázat).

Az alapítások számát tekintve az USA állt a harmadik helyen 270 alapítással, ugyanakkor a behozott tőke mennyiségét tekintve már ezen ország befektetői álltak az elsö helyen (mintegy 650 millió dolláros tókebefektetéssel).

Az 1991 -es vidéki beruházások megoszlása rendkívül tanulságos! Az osztrák, és a holland tökének legnagyobb befektetési terepe az Észak-Dunántúl térsége (az összes befektetések 70-80\%-a koncentrálódik ide). A svájci, a svéd és kisebb mértékben az amerikai befektetök viszont lényegében csak Budapestet és a környező településeket ismerik az 
Nagy Gábor: A külföldi tőke szerepe és térbeli terjedése Magyarországon.

Tér és Társadalom, 9. 1995. 1-2. 55-82. p.

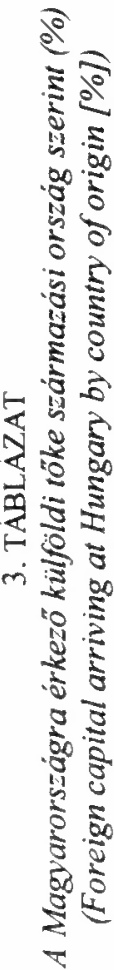

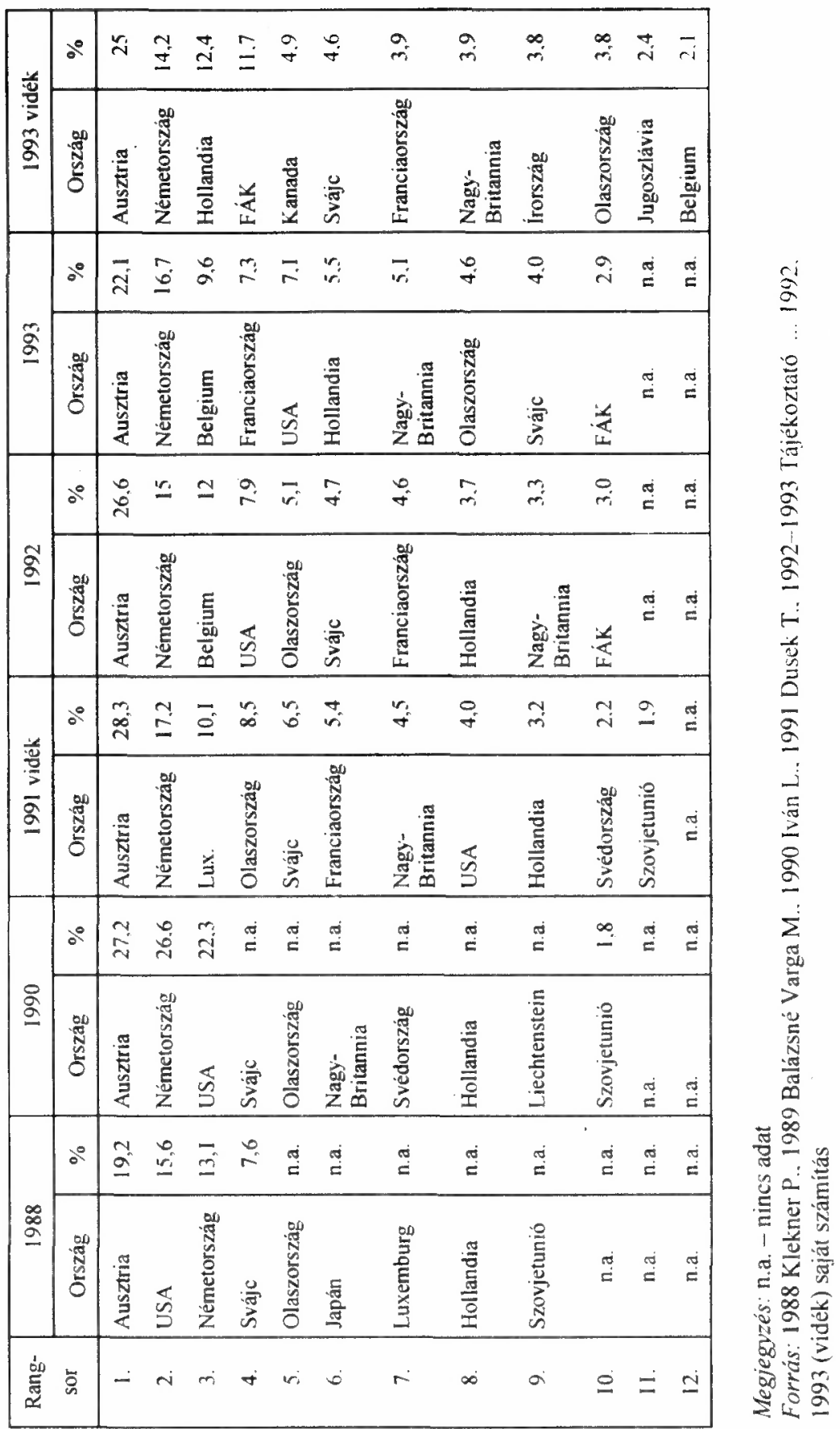


országból. A luxemburgiak a dél-alföldi és az észak-magyarországi megyéket, az olaszok az északi iparvidéket, Pest megyét és kisebb mértékben az Észak-Dunántúlt preferálják, a francia befektetök az északi megyék mellett Pest megyére és a Dél-Alföldre koncentrálnak, a németek az Észak-Dunántúl mellett a Dél-Dunántúlt és Pest megyét szemelték ki a terjeszkedés fỏ színterének. A legnagyobb beruházók klubja lényegében nem változott, legfeljebb a sorrendben történtek kisebb elmozdulások (Dusek J. 1993).

A vizsgált idöszakban növekedett a kizárólagos, illetve a többségi külföldi tulajdonban lévő vállalkozások aránya. Az új alapítások esetében a társaságok 35\%-ában a többségi tulajdonos a külföldi partner lett. Ez új jelenség a korábbi évekhez képest, hiszen 1989ben $13,4 \%$, egy évvel késöbb pedig $15,3 \%$ volt a hasonló cégek aránya. E csoporton belül a kizárólagos külfoôldi tulajdonba került cégek aránya meghaladta az egyharmadot, azaz az újonnan alapított cégek mintegy 13\%-a százszázalékos külföldi tulajdonba került. A megfeleló arányok 1989-ben 1,9\%, 1990-re 4,1\% voltak (Tájékoztató..., 1993).

Az 1992-ben bejegyzett vegyes vállalatokban a legnagyobb befektetök Belgiumból és Ausztriából származtak (9,4 illetve 9,2 milliárd forintnyi tőkével), utóbbi az alapitott szervezetek számában is az elökelő második helyen állt. Számszerüleg a legtöbb társaság alapításában a német cégek vettek részt, összesen 4,9 milliárd forintnyi tökével. Az év jelentös befektetöje volt még Svájc, Hollandia és Franciaország (egyenként 2-3 milliárd forintnyi külföldi tőkerésszel). A származási országok körében a befektetett tökenagyságot tekintve lényeges változást nem tapasztaltunk, viszont az alapított szervezetek számát tekintve feltúnik a jugoszláv, a kínai és a FÁK-beli befektetők korábbiakhoz viszonyitott magas száma. E három térségböl származó tỏke csaknem 600 vegyes vállalat alapításához járult hozzá, többhöz mint az osztrákok ( 580 alapítás). A FÁK - elsősorban Oroszország és Ukrajna - beruházóinak tókerészesedése is jelentős, 1992-ben meghaladta az másfél milliárd forintot (3. táblázat).

1993-ban a vidéki alapitásokban a korábbiakhoz képest lassú átrendezódés indult meg (Cégközlöny, 1993). A befektetett töke volumenének csökkenése mellett az egyes országok súlya eltérỏen változott. A legjelentősebb változások az élcsoportban: Hollandia a befektetések egynyolcadával a harmadik helyre jött fel Ausztria és Németország mögé, valamint a FÁK a negyedik helyre tört fel, jórészt egyetlen nagyberuházásnak köszönhetően. A középmezőnyben három új ország jelent meg a nagyobb befektetök között: Kanada, csaknem 700 millió forintnyi alapitó tỏkével (5.), Írország valamivel több mint félmilliárdos befektetéssel (9.) és Jugoszlávia 330 millió forintos befektetéssel (11.). A korábbi nagybefektetók közül az élcsoportban nincs jelen az USA, Svédország és Liechtenstein.

Az alapítások számát tekintve Németország és Jugoszlávia messze kiugrik a mezönyből (egyenként hétszáznál is több részvétellel), majd 355 vegyes vállalati alapítással Ausztria következik. Száznál több alapítással dicsekedhet a FÁK és Olaszország.

A befektetői viselkedéseket elemezve a két végponton a jugoszláv, illetve az ir példa áll. Elöbbi rengeteg apró - számos esetben nem jogi személyiségủ - cég alapitásában vett részt, melyek nagyon karakteresen a déli határ mentén tömörülnek. Az ír töke kisszámú - 
mindössze hét! - projektet választott ki, ám ezekbe egyenként is nagy volumenủ tőkét invesztál. A projektek megoszlása lényegében egyenletes volt az országon belül, erősebb koncentrációt az északi megyékben találtunk, ahol a korábbi ír vegyes vállalatok már sikerrel múködnek, és kedvező tapasztalatokat szereztek (Cégközlöny, 1993).

A vegyes vállalatokban meglévő átlagos külföldi tőkerész tovább növekedett 1992-ben. Többségi hazai tulajdoni aránnyal már csak a cégek 48\%-a alakult, ez még az 1991-es 65\%-hoz képest is nagyarányú csökkenést jelent (Magazin Kiadó, 1993). A legkisebb alaptőkével létrejött bt.-knél és kkt.-knál a legnagyobb arányú a külfơldi többségủ társaságok aránya, míg a részvénytársaságokban és a kft.-kben a belsó tulajdoni arányok megváltozását gyakran késỏbbre halasztják. A kizárólagos külföldi tulajdonban lévő vállalkozások aránya több mint kétszeresére nött az elözö évihez képest (27\%).

Az 1993-as évben a Cégközlöny adatai alapján a vidéki székhellyel alapított vegyes vállalatok 40,2\%-a alakult százszázalékos külföldi tulajdoni hányaddal, de tekintve, hogy ezek legnagyobb része betéti társaság, vagy minimális alaptőkével létrehozott kft., a befektetett tökéböl való részesedésük alig éri el a 18\%-ot.

\section{Vegyes vállalatok terjedése a megyékben, régiókban és a településhierarchiában}

Az 1988 végéig hazánkba érkezett külföldi tỏke erős területi koncentrációt mutatott. Budapest területén kívül mindössze 80 társaságot regisztráltak; ez alig több mint az akkor mükődő vállalkozások egyharmada (Klekner P. 1990). A vidéki székhellyel bejegyzett cégek bỏ egynegyede Pest megyében müködött, ami tovább erösitette a területi koncentrációt. A telephelyválasztást részben a fơváros kỏzelsége befolyásolta, másrészt a budapesti ipar kisebb egységei, illetve a hatvanas évektől a fóvárosból kitelepitett ipari üzemek bizonyos hányada szintén az agglomeráció településein talált magának telephelyet, hogy a fó felvevö piacától ne kerüljön nagy távolságra (4. táblázat).

A vidék egészét tekintve erős az ágazati koncentráció, az itt alapított cégek $90 \%$-a az ipar valamely ágazatához kötődik, összesen két mezőgazdasági, öt szolgáltató jellegü (ebböl egy tekinthető komolyabb nagyságrendü befektetésnek), és egy fejlesztési profilú beruházást tudtunk beazonosítani.

A külföldi tởke telephelyválasztásában a dőntéshozatali központ közelsége játszotta a döntő szerepet, emellett a müszaki és humán erőforrások erösebb koncentrációja hatott jelentösebb vonzeróvel a befektetni kívánó külföldiekre. Nem véletlen e szakaszban Budapest kiemelkedó szerepe, illetve az Észak-Dunảntúl megyéinek korai indulása sem.

Egy évvel késóbb a területi eloszlásban - az alapitások növekvő számának köszönhetỏen - lassú kiegyenlítódés indul el, amely elsősorban a nagyrégiókat tekintve igaz, az egyes megyék között azonban így is jelentős különbségekkel találkozunk (KOPINT$D A T O R G$, 1992). A legkevesebb vegyes vállalat Békés megyében alakult, szám szerint kilenc, míg a legtöbb Pest megyében. 


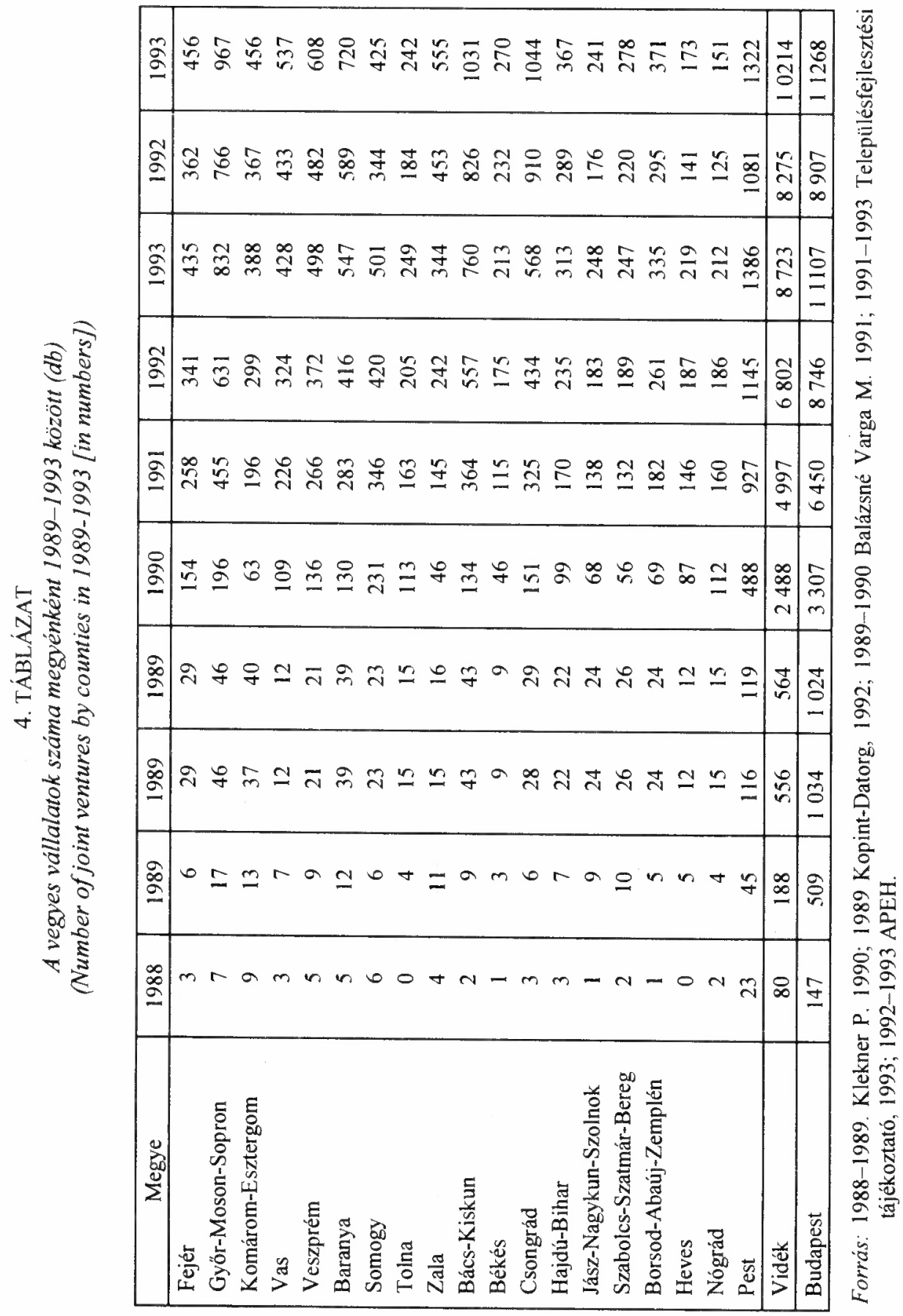


A vidéken található 564 vegyes vállalatból az akkori városok közel felében (84 településen) 437 társaság múködött. A fennmaradó 127 vidéki székhelyủ cégen 97 község osztozott (Balázsné Varga M. 1991). A vegyes vállalatok térbeli terjedésében - a megyék legnagyobb részében - elkülönül a megyeszékhelyek hierarchiaszintje. Pest megye vállalkozásai nélkül a vidéki alapítások $58 \%$-át tömörítették. A legerősebb megyei koncentrációk egyrészt a regionális központok esetében voltak megfigyelhetők, másrészt azokban a megyékben, ahol az átlagosnál jóval kevesebb alapításra került sor (Heves, Nógrád, Tolna, Vas).

A kiegyensúlyozottabb településállományú megyék esetében a vegyes vállalatok eloszlása is egyenletesebb, jó példa erre Bács-Kiskun megye, ahol a megyeszékhely mellett a „,kiskun” városok, valamint Baja és Kalocsa, sőt a falvak egy jelentős része is társasági székhellyé vált.

A falusi társaság alapításoknak három típusa különíthetỏ el, melyek a következö szakasz alapításaira is jellemzőek lesznek:

- legnagyobb számban a városi iparhoz kapcsolódó cégeket alapítottak elsősorban Budapest, kisebb számban Győr-Moson-Sopron és Veszprém megye ipari központjai közelében;

- a második csoportot típusosan a Balaton környéki - kisebb számban más idegenforgalmi - térségben alakult és az idegenforgalom köré szerveződött társaságok jelentik;

- a harmadik karakteresebb csoportba az alföldi „Homokhátság” falvai tartoznak, ahol a befektetések legnagyobb számban és legnagyobb tökével az élelmiszeriparba áramlanak.

A vidéki városok közül tehát elsősorban a megyeszékhelyek rendelkeztek megfelelö funkcionális szerkezettel, jelentős lokális piaccal ahhoz, hogy a külföldi töke az ipar mellett más ágazatokba is beléphessen. A kisebb városok és a községek vállalkozásai a helyi termelöüzemekhez kapcsolódva, illetve a helyi munkaerő meglétére települtek, esetleg valamely helyi termék kereskedelmére specializálódtak.

A vegyes vállalatok számának növekedése az 1990-1991-es szakaszban a területi dekoncentráció irányába hatott. 1990 végén már közel 2400 szervezet müködött vidéken, az elözö évinek több, mint négyszerese (Balázsné Varga M. 1991). Általános jelenséggé vált, hogy ekkorra minden megyében szinte valamennyi ágazatban megjelent a külföldi tỏke. A kereskedelmi ágazat az alapítások számát tekintve a legnagyobb csoporttá nőtte ki magát, megelözve az ipart. A társaság alapítások üteme azonban a szolgáltató ágazatokban volt a legmagasabb, majdnem másfélszerese az átlagos növekedési ütemnek.

A megyék versenyében kétirányú folyamat zajlott, miközben nagytérségi szinten további közeledést tapasztalhattunk. A korábban is kiemelkedỏen vonzó megyék megerösítették vezető szerepüket, ugyanakkor a korábban leggyengébb megyék részesedése érezhetően közeledett a középmezőnyhöz. A legjobbak csoportjáról lassan levált Baranya és Komárom-Esztergom megye, míg a másik oldalon elkezdődött Vas megye lassú felzárkózása (4. táblázat). A szélsỏ értékek: Pest megye 451 vegyes vállalati székhellyel (itt 
számolni kell az agglomeráció torzító hatásával), illetve Györ-Moson-Sopron 231 társasággal, a másik véglet Heves megye 44 cégközponttal. Pest megye nyomasztó fölénye valamelyest csökkent a többi megyéhez képest.

A nagy regionális központok továbbra is „tisztára söprik” a teret maguk körül. E centrumok megyéjükön belül ugyanazt a szerepet játsszák el, mint Budapest országos szinten, azaz erőteljesen koncentrálják a kereskedelmi és szolgáltatási ágazatba érkező tökét. A legerősebb koncentrációt Pécs környékén tapasztaltuk (aprófalvas faluhálózat, depressziós kisvárosi környezet), míg a legkisebbet Györ esetében (Sopron, Mosonmagyaróvár kiegyenlítỏ hatása).

A falusi településeken több mint félezer külföldi érdekeltségủ társaság múködött 1990 végén, $\mathrm{s}$ az egy évvel korábbihoz képest már 300 községben találtunk egy, vagy több vegyes vállalatot (Balózsné Vraga M. 1991).

A legnagyobb koncentráció - immár hagyományosan - Pest megyére jellemzö, hiszen a nem városi székhelyủ cégek 42,6\%-a települt oda. A megyében először volt lehetőség területi különbségek felvázolására. Ezek szerint a budapesti tömörülés „nyúlványának” tekinthetők északi irányban a Duna két partjának települései Vácig, valamint délnyugati irányban a Budaörssel fémjelezhető környék. Az alapítások száma a fóvárostól távolodva erőteljesen csökken, s a megye déli és keleti sávja beleolvad az alföldi átlagba.

Az Alföldön csak Bács-Kiskun megyében találtunk nagyobb számban falusi székhelyủ vegyes vállalatokat, melyek az élelmiszeripar mellett bérmunka típusú üzemeket müködtetnek (pl. textilipar). A dunántúli nagyobb ipari centrumok körül tovább folytatódott a vegyes vállalatok alapítása (Veszprém, Székesfehérvár, Esztergom). Országosan a legnagyobb mértékben azonban az idegenforgalom fogadta a falusi térségekbe áramló külföldi tökét.

Az 1991-ben bekövetkezett változások az elözỏ év fö tendenciáihoz képest nem mutatnak alapvetó eltérést a vegyes vállalatok területi eloszlásában. A nagytérségek szintjén lelassul, majd megáll a területi kiegyenlitódés (Településfejlesztési tájékoztató, 1993). Az észak-magyarországi megyékre a kisebb számú, de nagyobb tőkeerővel alapított egységek lesznek jellemzők, s egyre inkább ebbe az irányba mozdul el az észak-alföldi megyék befektetési szerkezete is (5. táblázat). A déli megyékben a nagyobb alapítási szám mellett a viszonylag alacsonyabb alaptökével létrejött egységek válnak dominánssá, mellettük kis számban találhatunk tőkeerösebb társaságokat általában egy-egy nagyobb, jól menó egység tőkebevonása kapcsán. A harmonikusabb méretbeli eloszlás az északnyugati megyékre és Pest megyére jellemzö, itt minden befektetői típus jelen van, s ez kiegyenlítettebb cégstruktúrát eredményez.

A megyék szintjén tovább folytatódott Pest megye tetemes elönyének lassú lemorzsolódása, az év végére 890 külföldi érdekeltségü társaság müködött itt, a vidéki székhelyú cégek 18,2\%-a. Tovább erősödött Györ-Moson-Sopron és Bács-Kiskun pozíciója, illetve Szeged és Pécs szerepének megerősődése következtében Baranya és Csongrád megye javított helyzetén (4. táblázat). 


\section{TÁBLÁZAT}

A vidéken befektetett töke megoszlása megyénként (\%)

(Distribution of the capital investments in the countryside, by counties, \%)

\begin{tabular}{|l|r|r|r|r|r|r|r|r|}
\hline Megye & 1988 & 1989 & 1990 & 1991 & 1992 & 1992 & 1993 & $\begin{array}{r}1993 \\
\text { vidék }\end{array}$ \\
\hline Fejér & & & & & & & & 9,2 \\
Györ-Moson-Sopron & 7,7 & 12,8 & 9,0 & 9,0 & 8,1 & 9,7 & 5,2 \\
Komárom-Esztergom & 12,3 & 11,6 & 11,0 & 9,4 & 8,6 & 6,0 & 5,7 & 5,2 \\
Vas & 1,7 & 2,7 & 2,0 & 3,6 & 3,1 & 8,3 & 7,8 & 3,4 \\
Veszprém & 13,7 & 11,0 & 7,3 & 10,6 & 10,5 & 2,9 & 2,9 & 2,7 \\
Baranya & 2,1 & 2,2 & 0,9 & 2,0 & 2,9 & 6,2 & 6,7 & 4,5 \\
Somogy & 2,8 & 2,6 & 2,4 & 1,7 & 1,0 & 1,9 & 1,9 & 4,1 \\
Tolna & 0,0 & 0,2 & 0,7 & 1,0 & 0,6 & 0,9 & 0,9 & 0,5 \\
Zala & 2,1 & 1,7 & 3,5 & 2,8 & 1,9 & 3,1 & 3,0 & 4,5 \\
Bács-Kiskun & 0,7 & 1,5 & 2,1 & 3,9 & 3,4 & 5,4 & 5,5 & 6,7 \\
Békés & 0,3 & 0,6 & 0,4 & 2,4 & 1,3 & 4,7 & 4,3 & 0,7 \\
Csongrád & 0,9 & 1,2 & 1,0 & 2,0 & 1,8 & 3,1 & 3,0 & 1,6 \\
Hajdú-Bihar & 2,6 & 8,1 & 6,8 & 3,6 & 3,5 & 4,0 & 3,8 & 1,8 \\
Jász-Nagykun-Szolnok & 0,3 & 1,4 & 0,7 & 0,4 & 1,3 & 3,9 & 3,8 & 2,3 \\
Szabolcs-Szatmár-Bereg & 5,6 & 6,5 & 6,0 & 3,5 & 2,0 & 1,7 & 1,6 & 1,4 \\
Borsod-Abaúj-Zemplén & 5,1 & 3,1 & 7,8 & 4,6 & 5,6 & 9,7 & 9,0 & 14,4 \\
Heves & 0,0 & 0,3 & 0,1 & 0,9 & 4,4 & 4,2 & 4,2 & 10,3 \\
Nógrád & 4,9 & 3,9 & 2,8 & 2,6 & 5,7 & 2,4 & 2,2 & 3,6 \\
Pest & 29,2 & 27,6 & 25,2 & 27,8 & 23,1 & 14,5 & 15,1 & 14,8 \\
\hline Vidék & 100,0 & 100,0 & 100,0 & 100,0 & 100,0 & 100,0 & 100,0 & 100,0 \\
\hline
\end{tabular}

Forrás: 1988-1989 Klekner P. (1990); 1990-1992 Magazin Kiadó, (1990), (1991), (1992); 1992-1993 APEH, 1992-1993; 1993 vidék, saját számítás.

Valamennyi észak-dunántúli megye az átlagosnál gyorsabb növekedést mutatott, így került Vas és Zala megye két év alatt a lemaradók (későn indulók?) közül a középmezőnybe. A szervezetek nagy száma és az egy vállalkozásra jutó alacsony átlagos tőke arra utal, hogy főként a határ közeli kisebb szervezetek, illetve magánszemélyek hozták létre a vegyes vállalatokat, melyeknek zöme kereskedelmi, szolgáltató és tanácsadó cég (5. táblázat). A kapcsolatok kései indulását magyarázza, hogy a határ túloldalán nem volt jelentỏs, tóke kibocsátóként is megjelenỏ gazdasági centrum. A vasi és zalai modell az országos tendenciákkal ellentétes irányt jár be, míg általában a megjelenö és sikeresen müködö nagyszervezetek példája húzza maga után a kisebb befektetöket, addig itt lényegében forditva zajlott a folyamat. A megjelenö kisbefektetők informális kapcsolatai után érkeztek meg a közepes méretủ partnerek (A modell érdekében most eltekintettünk az OPEL hatásától). 
Az eddig vizsgált időszakban Magyarország térszerkezetében a külföldi tőkeberuházások új elemként jelentek meg bizonyos térségekben. 1991-re már megfigyelhető volt erőteljes koncentrációk, csomópontok kialakulása. A legerösebb koncentráció a budapesti agglomerációhoz tartozó településeken tapasztalható, amely minden telepítő tényezöt tekintve a legelönyösebb helyzetben volt az országon belül. A másik fontosabb tömörüló zóna a Budapest-Bécs útvonal tágabb környezetében alakult ki, melyben a kedvezö földrajzi helyzet párosulva a meglévö korszerúbb ipari struktúrával, s épitve a meglévő, nagy hagyományokkal bíró termelési kapcsolatokra, s kapcsolódva a magántöke országosan is kiemelkedő aktivitásához vonzónak bizonyult a külföldi, elsősorban az osztrák és német befektetők számára.

Szintén kedvelt befektetési terület a fövárostól induló és Keszthelyig-Hévízig húzódó, Veszprémnél és Székesfehérvárnál kiszélesedő sáv, mely részben az idegenforgalomra és kapcsolódó ágazataira, részben a centrumok és a környező települések iparára koncentrálódik. Az ipari nagyméretủ vállalatokat jól ellenpontozzák a kisebb méretủ nagyszámú szolgáltató egységek.

Az utóbbi két évben egy új sáv látszik kirajzolódni az osztrák-magyar határ innenső oldalán, ahol kisszervezetek, magánszemélyek nagy számban alapítanak vegyes vállalatokat a kereskédelemben és a szolgáltatásokban. A térség elönyei közül a térbeli közelség játssza a döntő szerepet, melyet a korábban létező termelési kapcsolatok erősitenek.

Az ország többi részében nem alakultak ki összefüggő, nagy aktivitást mutató zónák. Az E5-ös út mentén Kecskemét és Szeged csomópontok vonzanak nagyszámú, de egyenként kis tőkét befektetni szándékozó vállalkozót. A további regionális központok - mindenekelött Pécs - számos vegyes vállalatnak adnak otthont, de ezekben legfeljebb közepes méretủ tókeállomány koncentrálódik.

A vegyes vállalat alapítás első nagy hullámában - 1989 és 1991 között - a befektetöket a magyar piacon való megjelenés, a vidéki központok esetében a lokális és regionális piacra való bejutás lehetősége, az alacsonyabb termelési költségek, a mérsékeltebb bérköltséggel alkalmazható képzett munkaerő vonzotta Magyarországra. Az adózási feltételek szintén fontos, bár nem döntö szerepet játszottak a telephélyválasztásban (Dusek T. 1993).

Az országon belüli letelepedést, azaz végsö soron a vegyes vállalatok térbeli eloszlását befolyásoló legfontosabb tényezók:

- a már kialakult külföldi tőke-koncentrációk, amelyeknek a kezdeti bizonytalan szakaszban különösen fontos szerepe van (információáramlás, személyes kapcsolatok, tapasztalatok átadása);

- a földrajzi helyzet (pl. a potenciális befektetök közelsége);

- a környezö területek gazdasági fejlettsége;

- a helyi gazdaság szerkezete;

- a közlekedési kapcsolatok;

- a helyi és regionális piac mérete és szerkezete;

- a kooperációs lehetöségek; 
- a helyi társadalom szerkezete (fóként az innovativitási faktorok, mint a szellemi potenciál, vagy a vállalkozói aktivitás);

- és végül, de nem utolsósorban a városi központok funkcionális gazdagsága, melyek közül különösen fontosnak tünnek az adminisztratív funkciók és az ágazati döntési központok.

A külföldi érdekeltségủ vállalkozások közül 1992 végén 8275 múködött vidéken, 3390 darabbal több, mint egy évvel azelött. Az alapítások üteme 1989 óta elöször volt lényegesen magasabb itt, mint a fơvárosban. A jegyzett tőkét vagy a devizában történt befektetéseket vizsgálva a megyék részesedése lényegében nem változott, azaz vidéken sokkal nagyobb arányban alapítottak kisebb méretủ vállalkozásokat, mint Budapesten.

A legtöbb vegyes vállalat 1992-ben is Pest megyében múködött, de a korábban már megállapított tendencia tovább folytatódott, csökkent a megye relatív súlya a vidéki alapításokban (4. táblázat). Ez évben először, már nem itt fektették be a legnagyobb tőkét a vidéki társaságokba, de a cégek átlagos mérete így is jelentősen meghaladja az országos átlagot (5.táblázat). A szervezetek ágazati és méretstruktúrája a föváros után a legkiegyensúlyozottabb, s feltünnek olyan vegyes vállalatok is, melyek kifejezetten a helyi szellemi potenciálra települnek: számítástechnika, $\mathrm{K}+\mathrm{F}$, oktatás. Ez utóbbi területen Pest megye nagyságrenddel megelózi a vidéki egyetemi városokat.

Csongrád, Bács-Kiskun és Győr-Moson-Sopron megyére 1992-ben is jellemző maradt az erös alapítási dinamika (Csongrádban egy év alatt hatszáz, Bács-Kiskunban négyszáz, Győr-Moson-Sopron megyében több mint háromszáz alapítást regisztráltak). Viszonylag magas volt az alapítások üteme Vas, Zala és Veszprém megyékben, melyek átlagos, vagy átlag alatti helyzetüket javították. Telítődni látszik Fejér és Komárom-Esztergom megye (és tulajdonképpen Pest megye is), hiszen az egy évvel korábbi szinten megrekedt az új társaságok száma.

Attól fuuggően, hogy a külföldi töke milyen ágazatokban koncentrálódik, mennyire szervesen épül be egy-egy megye gazdaságába, lehetőség nyílt területi típusok elkülönítésére (Meskó A. 1994).

Az első ,ipari vegyes” csoportba tartozik Pest, Borsod-Abaúj-Zemplén, Vas, Fejér és Györ-Moson-Sopron megye. Itt vitathatatlan a feldolgozóipari beruházások vezetỏ szerepe (1992 végéig a felsorolt megyék mindegyikébe több mint tízmilliárd forintnyi külföldi tỏke áramlott be.) Az alágazatok közül az élelmiszeripar a legjelentősebb fogadó ágazat a csoport majd minden tagjánál (kivétel Vas megye, ahol a gépipar). Minden megyében legalább négy-öt alágazatban félmilliárd forintnál is több tỏke koncentrálódik. Emellett a gazdasági szektorok majd mindegyikében 300 millió forintnál is nagyobb töke van lekötve (építöipar, kereskedelem, gazdasági szolgáltatások). Pest és Györ-MosonSopron megyében különösen erős a gazdaságot segitő szolgáltatások szerepe, melyek az erös helyi, illetve a fôvárosi ipar kiszolgálására alakultak. E csoport megyéiben a helyi gazdaság szerkezete, fogadókészsége eröteljesen serkenti a befektetéseket.

A második „egyoldalú ipari" csoporthoz tartozó megyék esetében szintén a feldolgozóipar áll a vezetö helyen, de mellette más ágazatban alig-alig jelenik meg a 
külfơldi töke. Ebbe a csoportba sorolhatjuk Bács-Kiskun, Békés, Jász-Nagykun-Szolnok, Heves és Nógrád megyéket. Az alföldi megyék esetében a kiegészítö ágazat általában a kereskedelem, míg az északiaknál a bányászat, esetleg az építőipar képviselteti magát szerényebb mértékben. A feldolgozóiparon belül az élelmiszer-feldolgozás, az építőanyag-ipar (helyi nyersanyagra települ), illetve a nyomdaipar súlya a meghatározó. Nógrád megyében a kohászat és a gépgyártás súlya kiemelkedő. A két északi megyében a legutóbbi időkig a nagyszervezetek uralták a helyi gazdaságot, melyek saját kereskedelmi, szolgáltató részlegekkel rendelkeztek, s tevékenységükkel lefedték a regionális piacot. A nagyszervezetek szétesése, válsága a gazdaságot segítő szolgáltatások szerveződésének eddig nem kínált ideális müködési feltételeket.

A harmadik „vegyes” csoportot azok a megyék alkotják, ahol az ipari befektetések szerényebb volumenüek voltak ugyan, de a külföldi tôke több más ágazatban is megjelent. Ide soroltuk Hajdú-Bihar, Csongrád, Zala, Veszprém, Somogy és Tolna megyéket (bár utóbbinál a külföldi befektetések mértéke még a feldolgozóiparban is rendkívül szerény.) A két alföldi megyénél a térszerkezet és a tőkevonzás szempontjából is meghatározó a megyeszékhely szerepe, melynek számos döntéshozatali funkciója, nagyméretü, koncentrált piaca kedvezö befektetési lehetőségeket kínál a külföldi partnerek számára. Az ipari szervezetek helyi egységeinek magánosítása ekkorra már jelentösen elörehaladt, s a szolgáltatások és a kereskedelem rá tudott szervezỏdni e megváltozott keretekre. A dunántúli megyék földrajzi helyzete - Tolna kivételével - kedvezönek mondható, a külföldi tőke lényegében az ipar összes alágazatában megjelent, sỏt Somogyban - vidéken legnagyobb volumenben - áramlott a mezögazdaságba a külföldi tőke.

A negyedik „átmenet $\imath^{\prime \prime}$ csoportot a köztes helyzetủ megyék alkotják, melyek az „ipari vegyes" és a "vegyes" csoport között helyezhetök el. Mind Baranya, mind KomáromEsztergom megyében a feldolgozóipar (megyénként hét-nyolc milliárd forint), ezen belül az élelmiszeripar (Baranyában az itt befektetett töke közel felével) és a gépipar (Komárom-Esztergom megyében az ottani külföldi beruházások felével) a legjelentösebb tỏkevonzó ágazat; mellette további ipari alágazatok: bányászat, építőanyag-ipar, illetve az építőipar és a gazdasági szolgáltatások koncentrálnak még jelentősebb tőkét. A külföldi töke összvolumene, ágazati megoszlása, illetve a megyék endogén erőforrásai lehetővé teszik fokozatos felzárkózásukat az elsö csoport megyéihez.

Az APEH adatbázisa szerint 1993-ban 4286 új vegyes vállalat kezdte meg müködését, ebböl 2361 szervezet Budapesten és 1925 vidéken. Ugyanerre az évre a Cégközlöny alapján összeállitott adatbázis szerint mindössze 1658 céget hoztak létre fővárosi székhellyel, és 2711-et vidékivel. A fơvárosi adatok szerint tehát több száz korábban „alvó" cég kezdte meg müködését, illetve számos vidéken bejegyzett társaság tette át székhelyét Budapestre, $s$ folytatja a további tevékenységét ott. Ugyanakkor a vidéken alapított cégek közül legkevesebb nyolcszáz vállalkozás nem, vagy nem vidéken kezdte meg mủködését 1993-ban. A folyamat méreteinél fogva is további kutatást igényel.

Az a folyamat, amely az 1989-1991 közötti éveket jellemezte, - azaz a vegyes vállalatok számának dinamikus növekedése és a külföldi töke lassú dekoncentrációja - 1992-ben 
lezárult. Helyette a vállalkozás alapitások ütemének mérséklödése mellett ismét erősödött a tőke területi koncentrációja, amely Pest megye mellett a Bécs-Budapest tengely megyéire, és kisebb mértékben a nyugati határszél megyéire is kiterjedt 1993-ban. Ezen területileg is összefüggő zónán kívül a legiparosodottabb megyékben (Borsod-AbaújZemplén, Baranya) kimondottan az iparhoz kapcsolódóan jelentek meg a külföldi befektetések.

A vidéken alakult vegyes vállalatok csaknem felét - az egy évvel korábbiakhoz hasonlóan - a kereskedelemben hozták létre, miközben ezen ágazat a jegyzett tőke csupán egynyolcadát képviselte. A gazdasági tevékenységet segítő szolgáltatásokban továbbra is jellemző volt a vállalkozás alapítások gyors üteme, több mint 130 szervezet alakult 1993ban közel hatszázmillió forintos alaptőkével. A pénzügyi szféra és a nem anyagi szolgáltatások minimális számban és tókeerővel jelentek meg vidéken, elsősorban a regionális központokban. A legvonzóbb ágazatnak azonban továbbra is a feldolgozóipar bizonyult, ezen belül alágazatonként másfél-két milliárdos jegyzett tókével a gépipar, a vegyipar és a kohászat koncentrálta a legnagyobb tökét.

Az 1993-ban alapított vegyes vállalatok településenkénti elhelyezkedését a Cégközlöny adatai alapján dolgoztuk fel. Figyelembe véve az adatok használhatóságára vonatkozó esetleges korlátozó tényezóket, mégis ez volt az egyetlen közelítőleg teljes forrás, mely a térbeliségről bizonyos információt tudott nyújtani.

Az 1992-ig tartó területi dekoncentrációs folyamat 1993-ban ismét megfordult és Budapest vonzása fokozatosan egyre erősebbé vált anélkül azonban, hogy - miként azt korábban tapasztalhattuk - erösítette volna Pest megye, illetve az ottani centrumok szerepét.

A befektetések legfontosabb célpontjai 1993-ban is a nagyvárosi hálózat egyes elemei maradtak, hiszen az újonnan alakult cégek $43 \%$-a, a jegyzett tỏke $42 \%$-a e 21 városra koncentrálódott (nagyváros alatt az ötvenezer lakosnál népesebb városok csoportját értjük Budapest nélkul). 1990-ben a nagyvárosokban az összes vidéki vegyes vállalat $40 \%$-a székelt (Balázsné Varga M. 1991). A többi város részesedése az alapításokból 1990-hez képest csökkent, 34\%-ról 30\%-ra. Az aránycsökkenés nagyobbrészt a községek javára következett be, ami azért is feltünő, mivel a közben eltelt években 25 községet várossá nyilvánítottak. Csekély számban ugyan, de elöfordultak olyan városok, ahol 1993-ban egyáltalán nem volt külföldi befektetés.

A tőke hierarchikus terjedése a településhálózat szintjeinek fejlettségét, funkcionális gazdagságát, vagy szegénységét is tükrözi, ezért érdemes az egyes hierarchiaszinteket, és azokon belül a regionális sajátosságokat is megvizsgálni (6. táblázat). 


\section{TÁBLÁZAT}

Vegyes vállalat alapitások az alaptőke nagyságát tekintve, 1992-1993

(Joint venture foundations by scale of capital assets, 1992-1993)

\begin{tabular}{|c|c|c|c|c|c|c|}
\hline Megye & $\begin{array}{l}2 \text { Mrd Ft } \\
\text { felett }\end{array}$ & $\begin{array}{c}1-2 \\
\mathrm{Mrd} \mathrm{Ft}\end{array}$ & $\begin{array}{c}0,5-1 \\
\text { Mrd Ft }\end{array}$ & $\begin{array}{l}0,2-0,5 \\
\text { Mrd Ft }\end{array}$ & $\begin{array}{l}0,1-0,2 \\
\text { Mrd Ft }\end{array}$ & $\begin{array}{r}0,05-0,1 \\
\text { Mrd Ft }\end{array}$ \\
\hline Fejér & Dunaújváros & & \begin{tabular}{|l|} 
Székesfehér- \\
vár
\end{tabular} & & $\begin{array}{l}\text { Iszkaaszent- } \\
\text { györgy }\end{array}$ & \\
\hline $\begin{array}{l}\text { Györ- } \\
\text { Moson- } \\
\text { Sopron }\end{array}$ & & Sopron & Györ & Nagycenk & $\begin{array}{l}\text { Sopronhor- } \\
\text { pács }\end{array}$ & $\begin{array}{l}\text { Sopronkö- } \\
\text { vesd }\end{array}$ \\
\hline $\begin{array}{l}\text { Komárom- } \\
\text { Esztergom }\end{array}$ & & & & Tatabánya & $\begin{array}{l}\text { Esztergom, } \\
\text { Dorog, } \\
\text { Gyermely, } \\
\text { Bábolna }\end{array}$ & \\
\hline Vas & & & Celldömölk & $\begin{array}{l}\text { Szombathely, } \\
\text { Sárvár }\end{array}$ & & Körmend \\
\hline Vešprém & & & & & $\begin{array}{l}\text { Veszprém, } \\
\text { Várpalota }\end{array}$ & $\begin{array}{l}\text { Ajka, } \\
\text { Devecser, } \\
\text { Csopak }\end{array}$ \\
\hline Baranya & & Pécs & & & & \\
\hline Somogy & & & $\begin{array}{l}\text { Balatonfeny- } \\
\text { ves }\end{array}$ & Kaposvár & \begin{tabular}{|l} 
Siófok, \\
Táb
\end{tabular} & $\begin{array}{l}\text { Zamárdi, } \\
\text { Csurgó }\end{array}$ \\
\hline Tolna & & & & & Bátaapáti & Szekszárd \\
\hline Zala & & Nagykanizsa & & Zalaegerszeg & Keszthely & \\
\hline Bács-Kiskun & & & $\begin{array}{l}\text { Kecskemét, } \\
\text { Hajós }\end{array}$ & Baja & & $\begin{array}{l}\text { Dunavecse, } \\
\text { Kiskun- } \\
\text { félegyháza, } \\
\text { Nyárlörinc, } \\
\text { Tiszakécske }\end{array}$ \\
\hline Békés & & & & & Békéscsaba & $\begin{array}{l}\text { Gyoma- } \\
\text { endröd }\end{array}$ \\
\hline Csongrád & & & Szeged & Csongrád & & $\begin{array}{l}\text { Hódmező- } \\
\text { vásárhely, } \\
\text { Szentes }\end{array}$ \\
\hline Hajdú-Bihar & & Debrecen & & $\begin{array}{l}\text { Hajdúbö- } \\
\text { szörmény }\end{array}$ & & $\begin{array}{l}\text { Balmazúj- } \\
\text { város, Kaba }\end{array}$ \\
\hline $\begin{array}{l}\text { Jász- } \\
\text { Nagykun- } \\
\text { Szolnok }\end{array}$ & & Szolnok & & & & Jászberény \\
\hline $\begin{array}{l}\text { Szabolcs- } \\
\text { Szatmár- } \\
\text { Bereg }\end{array}$ & & Nyíregyháza & & & & Vasmegyer \\
\hline
\end{tabular}


6. táblázat folytatás

\begin{tabular}{|c|c|c|c|c|c|c|}
\hline Megye & $\begin{array}{c}2 \text { Mrd Ft } \\
\text { felett }\end{array}$ & $\begin{array}{c}\text { 1-2 } \\
\text { Mrd Ft }\end{array}$ & $\begin{array}{c}0,5-1 \\
\text { Mrd Ft }\end{array}$ & $\begin{array}{l}0,2-0,5 \\
\text { Mrd Ft }\end{array}$ & $\begin{array}{l}\mathbf{0 , 1}-0,2 \\
\text { Mrd Ft }\end{array}$ & $\begin{array}{c}0,05-0,1 \\
\text { Mrd Ft }\end{array}$ \\
\hline $\begin{array}{l}\text { Borsod- } \\
\text { Abaúj- } \\
\text { Zemplén }\end{array}$ & & Miskolc & & $\begin{array}{l}\text { Sátoraljaúj- } \\
\text { hely, Sáros- } \\
\text { patak, Tokaj, } \\
\text { Pálháza, } \\
\text { Alsózsolca, } \\
\text { Rudabánya }\end{array}$ & $\begin{array}{l}\text { Borsod- } \\
\text { nádasd }\end{array}$ & $\begin{array}{l}\text { Ózd, } \\
\text { Tiszaújváros, } \\
\text { Mezózombor }\end{array}$ \\
\hline Heves & Hatvan & & $\begin{array}{l}\text { Eger, } \\
\text { Gyöngyös }\end{array}$ & & & \\
\hline Nógrád & & Salgótarján & & Pásztó & $\begin{array}{l}\text { Bátony- } \\
\text { terenye }\end{array}$ & $\begin{array}{l}\text { Szécsény, } \\
\text { Nagyoroszi, } \\
\text { Drégely- } \\
\text { palánk }\end{array}$ \\
\hline Pest & & Törökbálint & $\begin{array}{l}\text { Vác, } \\
\text { Gödöllö, } \\
\text { Zsámbék }\end{array}$ & Szentendre & $\begin{array}{l}\text { Kerepes- } \\
\text { tarcsa }\end{array}$ & $\begin{array}{l}\text { Csömör, } \\
\text { Pusztavacs }\end{array}$ \\
\hline
\end{tabular}

Forrás: A Cégközlöny 1993. évfolyamának számai

Értelmezésünk szerint összesen 21 város tartozik a nagyvárosi kategóriába. A kedvező földrajzi helyzetü, sokoldalú gazdasági potenciállal rendelkező nyugat-dunántúli kisebb központok (mindenekelött Sopron, Szombathely, kevésbé Zalaegerszeg és Nagykanizsa) erőteljesen felzárkózóban vannak e csoporthoz. Szintén feljövőben van Székesfehérvár, melynek kedvezỏ potenciálját egyre nagyobb számban fedezik fel világcégek is, és Kecskemét, mely részben a fơváros jó elérhetóségéből profitál, illetóleg a jugoszláv befektetói kör alapításaiból részesedik (6. táblázat).

Az Alföldön az igazán jelentős centrumok rendkivül erőteljesen koncentrálják a külföldi érdekeltségú társaságokat ( $75-90 \%$-ban saját megyéjükön belül), csak Szeged környékén tapasztalhatók jelei a városkörnyéki települések megnövekedó aktivitásának az utolsó két évben. A kiegyenlítettebb eloszlás csak Bács-Kiskun megyéhez köthetỏ, ahol a településhálózat sajátosságai indokolják ennek meglétét.

A Dunántúlon több megye esetében is kiegyenlítettebb a települések - ezen belül elsósorban a városok hierarchikus megoszlása $-\mathrm{s}$ ez a szervezetek térbeli eloszlásában is követhető. Komárom-Esztergom megyében Tatabánya súlyát jól kiegyenlíti Esztergom, Tata, Oroszlány, Komárom és Dorog, melyek együttesen a tatabányai székhelyủ cégeknél két és félszer több vegyes vállalatnak adnak otthont.

Hasonlóan egyenletes eloszlást tapasztalhatunk Somogy megyében is, ahol a Balatonparti kisvárosok vonzása jól ellensúlyozza Kaposvár vonzerejét. Ugyanakkor éppen Somogynál látható, hogy a belső területek - beleértve a centrumokat is - alig részesednek a külföldi befektetésekböl. 
A középvárosi kategória (30-50 ezres népességszám) mindössze 18 települést tartalmaz, de ezek funkcionális és regionális hatóköre meglehetősen széles skálán szóródik. Kettő közülük megyeszékhely, de találunk köztük paracentrumokat akár fél megyére kiterjedö vonzással (Baja, Gyöngyös). Ha az első két kategória városainak együttes vonzását tekintjük, újabb két-, illetve hárompólusú megyék állnak elöttünk, ahol a vegyes vállalatok 80-90\%-án e néhány település osztozik.

A kisvárosi kategória rendkívül vegyes képet mutat. Jó néhány település csak a legutóbbi időkben nyerte el a városi rangot, funkcionális szerkezete gyakran hiányos, helyi piaca kicsi, regionális vonzása kialakulatlan. Közülük az 1993-as évben nyolcvanban jelent meg külföldi töke.

Meglehetősen gyenge az alföldi kisvárosi hálózat vonzereje a befektetők között, az egyetlen kivételt Bács-Kiskun megye jelenti.

Jelentôs sürüsödés figyelhető meg a vegyes vállalatok számát tekintve a Balaton-parti kisvárosokban, ahol az idegenforgalomra felfủzödő gazdasági ágak mindegyikében megjelent a külföldi töke. A Komárom-Esztergom megyei koncentrációt segíti, hogy a megye városait szinte felfüzi a Bécs-Budapest tengely (vasút és közút egyaránt).

A kisvárosok sajátos csoportját alkotják azok, melyekben egyszeri jelentős alapítás történt, viszonylag jelentős tókével. Ez általában egy-egy helyi feldolgozóipari üzemet, vagy más helyi erőforrást érintett. Mivel a befektetések gyakran funkcióhiányos területen történtek, ezért gazdasági és társadalmi szerepük óriási lehet. Ha e befektetők megtalálják számításukat az adott településen, ez ösztönözhet további cégeket is a beruházásokra, mely az átstrukturálódás és a foglalkoztatás szempontjából nagy jelentỏséggel bír.

Pest megye településszerkezete sajátos, hiszen itt a közép- és kisvárosi kategóriában 16 település is található. Legtöbbjük vonzó befektetési célterület a külföldiek számára, de ebben nem elsősorban a városi funkciók magas koncentrációja, vagy a lokális piac fontossága fejeződik ki, hanem földrajzi helyzetüket értékelik ennyire pozitívan a befektetök. Bizonyíték erre az ötezernél népesebb községek aránya a befektetésekben (91 vegyes vállalat, több mint százmillió forintos jegyzett tỏkével 1993-ban).

A községekben a vidéken befektetett tőke 27,6\%-a koncentrálódott 1993-ban. Az átlag mögött azonban jelentős területi különbségek húzódnak meg. Az alföldi megyékben a falusi települések részesedése a befektetett tökébool vagy az alapitások számából igen alacsony, dacára a községek nagy átlagos méretének. Ám sem a funkcionális ellátottság, sem a helyi gazdaság szerkezete, sem a helyi társadalom kvalifikáltsága, sem pedig az infrastruktúra állapota nem vonzza a befektetőket, a földrajzi helyzet kedvezőtlenségéröl nem is beszélve. Természetesen azt is figyelembe kell venni, hogy az urbanizáció irányába elmozdult falvakat az utolsó évtizedben nagyrészt várossá nyilvánították, így ezek már a kisvárosi szinten lehettek összevethetők.

A falvak jelentős hányadát csak az 1992-1993-as utolsó befektetési hullám érintette. Általában nehezítette a falusi térségekben a vegyes vállalatok letelepedését a jövedelmek 25-30\%-os visszaesése az elmúlt négy évben, valamint a mezőgazdaság - a korábbi húzóágazat - körüli tulajdoni zürzavar. Az apró-, kis- és középfalvakban alapvetöen az 
egyszeri, nagyobb vagy közepes tőkével történt beruházások a meghatározók, elsősorban a helyi iparban, a bányászatban. Nagyobb számú, de kisebb tökével megvalósuló beruházások eleddig az idegenforgalmi térségek falvaiban jelentek meg (6. táblázat).

A településhierarchia szintje szerepet játszik a külföldi érdekeltségú társaságok telephely választásában, de ezen belül léteznek fontos makro-, mezo- és mikrotérségi különbségek. A kisvárosi kategória vonzereje szempontjából a településállomány többi eleme lehet befolyással. A föváros a saját ", holdudvarában" erösiti, mig a vidéki nagycentrumok gyengitik a vonzást, lényegében függetlenül a kisváros központi szerepköreitöl. Fontos differenciáló tényezö a földrajzi helyzet, ezen belül elsősorban a határmentiség, valamint az elérhetöség, melyek felértékelik a nyugati, illetve a Bécs-Budapest tengely kisvárosait, de leértékelik a többieket. A falvak esetében a legfontosabb a természeti potenciál szerepe (idegenforgalom, vagy ásványkincsek), illetve a szükebb térség gazdasági szerkezete, potenciálja, a piaci kereslet a meghatározó.

\section{A vegyes vállalatok terjedésének trendjei és a regionális politika}

Az 1993-as év szakaszhatár a külföldi tőke mennyiségi jellemzöit, strukturális megoszlását és területi elhelyezkedését tekintve.

A tókeimport dinamikája lassulni látszott 1992-93-ban, és ez a tendencia valószínüleg a kővetkezó években sem változik számottevően. A vegyes vállalatok alapítása a korábbiakhoz képest kedvezőtlenebb körülmények közơtt történik majd: jóval kevesebb külfôldi érdekeltségủ vállalkozás kaphat adókedvezményt, és ezek időtartama is rövidebb lesz. Vannak azonban olyan gazdasági szférák - a feldolgozóipar néhány ágazata, pénzügyek, biztosítás -, amelyekben továbbra is érvényes marad a korábbi szabályozás. (Ez a kelet-közép-európai országok között kifejezetten liberálisnak mondható.)

A tökeimport dinamikája lassulásának hatásait három alapvetóen fontos aspektusból kell elemeznünk: a befektető kiléte, a külföldi tőkebefektetések gazdasági struktúrára gyakorolt hatása, valamint a területi különbségek oldaláról. Megítélésünk szerint Magyarországon eddig három befektetői típus jelent meg (Herczeg J. 1993):

a) az elsö az intézményi befektetők köre, amelyre jellemzö, hogy résztulajdont igyekeznek szerezni a hazai vállalatokban, nem törekednek a vállalat múkỏdésének kizárólagos ellenőrzésére, és bármikor hajlandók részesedésüket készpénzért vagy más társaságok részvénypakettjéért eladni, illetve elcserélni;

b) a második csoporthoz tartoznak azok a nagyvállalatok, melyek legalább az európai (egységesülö) piacon ismertek és számottevő részesedéssel rendelkeznek; jellemzỏ viselkedésükre, hogy kizárólag többségi (lehetőség szerint 100\%-os) részesedést szereznek, egyedül kívánnak dönteni a stratégiai kérdésekben, igyekeznek magyar partnereiket kivásárolni vagy azok részesedését jelképesre csökkenteni; ök többnyire szakmai befektetók és nagy súlyt fektetnek a minőségre, a márkavédelemre, jelenlétük ezért pozitív a magyar 
gazdaságban, hiszen magas szintủ követelmények elé állitják a hazai beszállítókat, ök a legfontosabb mozgatói a technológia transzfernek, vagyis stratégiai befektetők;

c) a harmadik típus a kisbefektetőké, ők azonban viselkedésük alapján legalább két csoportra oszthatók: egy részük a gyors megtérülés és nagy profit reményében alapít vállalkozást kis tő́kével, általában a tercier szektorban; a vállalkozás jövedelmezőségének csökkenésekor tőkéjét gyorsan átcsoportosítja. A kisbefektetők másik csoportja a hosszabb távú megtérülés reményében érkezik, igyekszik már müködő vállalkozásba betársulni, gyakran lehetőséget, tőkét nyújtva a magyar vállalkozók számára; az operatív irányítást rendszerint átengedi a nagyobb helyismerettel rendelkező hazai partnernek; a nyugati határszélen néhány esetben már megfigyelhetó, hogy ezeket a külföldi tökéstársakat a jól müködő vállalkozásokból a magyar fél kivásárolja.

A szabályozásban és makrogazdasági folyamatokban bekövetkezỏ változások miatt a befektetök összetételében lassú eltolódás várható: a nagybefektetők, valamint az intézményi befektetök figyelme a privatizáció nyújtotta lehetőségek, valamint az infrastruktúra-fejlesztési projektek felé fordul, míg a kisbefektetők közül csökkenhet a „kalandorok" szerepe, a többi kisbefektető beszállitói és szolgáltatói tevékenységet folytathat.

A magyar területi fejlödésben tapasztalható fơváros-vidék dichotómia a vegyes vállalatok területi diffúziójában is megjelenik: a gazdasági fejlödés fontos, dinamikus elemeinek tekinthető külfơldi részvételü gazdasági szervezetek koncentrációja az erőforrások egyfajta újraközpontosítására utal. A területi különbségeknek azonban megjelenik egy újabb szintje is - jól tükrözi ezt a vegyes vállalatok területi terjedése -, amely a Dunántúl északi és nyugati megyéi és az ország többi térsége között erősödött fel. Az észak-dunántúli „aktív zónában” a külföldi tókebefektetések ágazati struktúrája az elmúlt években egyre szervesebbé vált: megjelentek a gazdasági élet valamennyi szférájában. Ezzel a sokoldalúsággal kezdetben csak Budapestnél, majd a budapesti agglomeráció kisvárosaiban, 1992-93-ban pedig már Észak- és Nyugat-Dunántúl nagy- és középvárosaiban is találkozhattunk.

A külföldi tỏke térbeli terjedésének leírására a hierarchikus és a szomszédsági modell csak egyuittesen alkalmas. Az utóbbi jellemzó a nagyvárosok - mindenekelött Budapest környékén, valamint a határmenti térségekben. A határmenti fekvés alapvetöen befolyásolja a befektetett tőke származási helyét, s ezzel együtt nagyon gyakran a viselkedését is.

A hierarchikus terjedés sajátosságait a települések helyi gazdaságának ágazati szerkezetében követhetjük. A külföldi töke elsö lépésként a kereskedelemben és a feldolgozóiparban jelenik meg. A következő fázisban bövül az ipari vegyes vállalatok köre, ezek többségükben kis- és közepes méretú vállalkozások beszállítói funkciókkal. Ha a térségben megindul a gazdasági fellendülés, akkor jelennek meg nagyobb számban a gazdasági szolgáltatással foglalkozó kisvállalkozások, illetve az építőipari tervező és kivitelezö cégek. A falvak, sőt a kisebb városok többsége sem tudott túllépni az első szakaszon (a községek nagyobb részében és számos kisvárosban egyáltalán nem jelent meg 
külföldi tőke). A Nyugat- és Észak-Dunántúlon érzékelhetők annak jelei, hogy nemcsak a nagyvárosok, de a településhierarchia alacsonyabb szintjein elhelyezkedő városok, esetleg községek is túljutottak az elsô szakaszon.

Nem elegendô tehát a külföldi tőkebefektetések volumenét vizsgálni egy-egy megyében vagy régióban, hanem azok strukturális sajátosságait, helyi gazdaságba való beépülését is át kell tekinteni. Ilyen megközelítésben Magyarországon a területi különbségek növekedéséröl beszélhetünk, amely elsősorban szerkezeti sajátosságokon keresztül fogható meg, ideértve a helyi gazdaság innovációs készségét, amely lemérhető a külföldi tőkével való együttmúködési képességén is. A térszerkezeten belül erősödó különbségek az ország északnyugati és többi része között szükségessé teszik az állam aktív szerepvállalását abban, hogy ösztönözze a külföldi tóke beáramlását az egyes régiókba.

A gazdaságpolitika különféle eszközökkel kísérli meg támogatni a külföldi tőke letelepedését az országban. Ezeknek az eszközöknek és intézményeknek természetesen vannak területi hatásai, ső́t magában a regionális politikában is találunk különbözó ösztönzőket a külföldi, de a hazai érdekeltségú vállalkozások letelepedésére, létrehozására is. Nem célja a tanulmányunknak, hogy részletesen tárgyaljuk és értékeljük az eddigi gazdasági intézkedések vállalkozás-támogatási rendszereit.

Megemlítjük, hogy a külföldi vállalkozások számára a Befektetés Ösztönzési Alap kínál lehetôséget a vállalkozás megtelepedéséhez, telephelyi és működési feltételeinek kialakításához. Ebben az alapban nem, vagy csak áttételesen jelennek meg regionális szempontok, inkább az ágazati és befektetési preferenciák érvényesülnek. Természetesen egyegy jelentősebb vállalkozás erőteljes hatással van az adott térség fejlődésére, gazdasági folyamatainak élénkítésére, azonban célirányos, kimondottan a regionális strukturális feszültségeket oldó támogatások ebben a központi alapban nem találhatók.

A Területfejlesztési Alapban viszont - amely hivatott a regionális különbségeket mérsékelni - egyértelmü kritériumok jelennek meg a fejletlen, elmaradott régiók felzárkóztatására, az ottani infrastrukturális különbségek mérséklésére, gazdasági szerkezetük átalakítására. A pontos elvekkel és célokkal mủködö alap kimondottan a különféle mutatók szerint meghatározott és ennek megfelelöen mereven elhatárolt térségekben használható fel, így az ottani gazdasági bázisok megújitását, azok átalakítását szolgálhatja a rendelkezésre álló összegekkel.

A tapasztalat az, hogy a jelentősebb és tartósan berendezkedni kívánó külföldi tỏke azokba a térségekbe települ, ahol kedvezöbb az infrastrukturális ellátottság (ezen belül is a telefon ellátottság, a közlekedési kapcsolatok, a telephely biztosítása a legfontosabb), ahol a munkaerő képzettebb, ugyanakkor költségei nem magasak és valamilyen letelepedési támogatásban (helyi adókedvezmény, olcsóbb telephely, gyorsabb ügyintézés) részesül. Ezeknek a kritériumoknak az elmaradott, a hátrányos helyzetú térségek nem, vagy igencsak nagy áldozatokkal tudnak eleget tenni.

A Területfejlesztési Alap tehát segíti az elmaradottnak itélt térségekben a külföldi érdekeltségü vállalkozások megtelepedését, azonban éppen ezen térségek komplexen 
kedvezötlen helyi tényezöik következtében csak mérsékelt számban tudnak fogadni külföldi vállalkozókat.

A különféle központi alapok támogatást nyújtanak a letelepedni szándékozó külföldi érdekeltségủ vállalkozásoknak, azonban célrendszerükben nem jelennek meg területi, regionális szempontok, támogatási elvek. Az igényelhető preferenciák kimondottan ágazati vagy szakmai célokhoz kötődnek, holott a gazdasági szereplök megjelenése, térségi és települési folyamatok tömegét indíthatja el.

A külföldi érdekeltségú vállalkozások megtelepedésére vonatkozó központi kormányzati intézkedések, mint azokról korábban már írtunk, kimondottan a vállalkozások számára határoznak meg kedvezményeket, ösztönzöket, sajnos egyre gyérebb, behatároltabb sávban. Ezek nem differenciálnak az ország térségei között, nem határozzák meg, hogy a fejlettebb régiókban mérsékeltebb, míg a fejletlenebb térségekben esetleg magasabb kedvezmények járhatnak. Fontosnak tartjuk, hogy ezen általános gazdasági ösztönzések köre bővüljönn, sőt azokba különbségek épüljenek be a területi típusok alapján, mert a jelenlegi rendszer csak újratermeli a regionális különbségeket és alapvetően nem ösztönöz a kevésbé fejlett térségekben a külföldi befektetésekre.

A helyi önkormányzatokra hárulna az a feladat és egyben teher, hogy egyrészt közvetlen pénzügyi ráhatással, a helyi adókon keresztül, másrészt pedig különféle települési támogatásokkal ösztönözzék a kulföldi töke letelepedését. Vizsgálataink alapján megállapithatjuk, hogy az önkormányzatok befolyásolási eszközei nagyon korlátozottak a vállalkozások támogatásában, a külföldi töke letelepítésében (Rechnitzer J.-Sipák T. 1993). Egyik oldalról az önkormányzatoknak érdeke, hogy kivessék az egyes helyi adófajtákat, így bevételhez jussanak, másik oldalról szeretnék ha minél több vállalkozás választaná székhelyének a települést. Ennek az ellentmondásnak a feloldása aztán számos formában jelenik meg. A nagyvárosok inkább a jelentősebb összegü külföldi érdekeltségú vállalkozásnak adnak kedvezményeket, míg a közép- és kisvárosokban nem, vagy nagyon korlátozottan élnek a helyi adók mérséklésének lehetőségével, szemben a falvakkal, ahol - talán a jobb anyagi helyzet és a feszítőbb foglalkoztatási gondok miatt -hosszabb-rövidebb időre mérséklik vagy elengedik a helyi adókat. Azt nem tapasztaltuk, hogy például a nagy- és középvárosokban éppen a városfejlesztési elvek következtében prioritásokat jelöltek volna meg a vállalkozások fogadásában, azaz, hogy a városfejlesztés szempontjából meghatározó kulföldi érdekeltségủ vállalkozások minden egysége kedvezményeket kapott volna, míg ebbe az a koncepcióba nem illők ettól elesnének. Napjainkra az önkormányzatok a szelektálásig nem jutottak el.

A másik szféra, a különféle támogatások, amelyek az olcsóbb telek, ingatlan eladástól kezdve a helyi megrendeléseken át egészen a letelepedés szervezéséig terjedhetnek. A skála széles, minden helyi közösség az ottani adottságai, a szakembereinek képessége, nyelvismerete, kapcsolatai révén kínálhat változatos segítséget a letelepedéshez.

Az elemzések bizonyították, hogy a jó szándékú támogatásban nem volt hiány, sőt az önkormányzatok mindent megmozgattak, hogy a jelentkezőknek, az érdeklödőknek segitsenek, azok letelepedési szándékát valóra váltsák. A meghiúsult esetek többségében 
nem a helyi akadályok játszották a fö szerepet, hanem a külföldi partnerek nem kellö ország-gazdaság ismerete, a különféle központi hivatalok bürokratizmusa, a pénzintézetek nehézkedése, a piac nem kellö felmérése, a támogatások nem ismerése és azok túldimenzionálása, vagy éppen egy másik település által kinált jobb lehetőségek, feltételek.

A regionális politikában mind országos, mind helyi szinten csak közvetetten jelenik meg a külföldi érdekeltségủ vállalkozások támogatása, azok letelepedésének ösztönzése. A különféle központi alapokban és általános kedvezményekben nincsenek, illetve erỏsen megkötötten jelennek meg regionális orientációk a külföldi tőke letelepítésében. Míg a helyi önkormányzatok éppen szúkös forrásaik miatt egyrészt rákényszerülnek a helyi adók - számos esetben a törvényi lehetőségeknél mérsékeltebb - kivetésére, másrészt anyagi (ez alatt értjuk a létesítményeket, földet, más objektumokat) eszközökkel nem, vagy csak nagyon korlátozottan képesek segíteni a külföldi vállalkozások telephely választását.

\section{Irodalom}

A külföldi tôke megjelenése a megyékben 1990-ben. Kopint-Datorg, Budapest, 1992.

APEH adatbázis a külfơldi érdekeltségủ társaságok területi elhelyezkedéséről 1992.,1993.

Balázsné Varga M. (1991) A külföldi tőkerészvételü vegyes vállalatok szerepe a magyar gazdaságban. (Kézirat) BUVÁTI, Budapest, $57 \mathrm{o}$.

Borszéki Zs. (1992) Vegyes vállalatok a hazai fogyasztási-cikk piacon. Kereskedelmi Szemle, 12. 1-6. o

Cégközlöny 1993. évfolyamának számai.

Dicházi B. (1992) Müködótőke-import. Figyelö 1992. november. 19. 13. o.

Dusek T. (1993) A vegyes vállalatok megtelepedésének feltételei. Diplomamunka, SZIF, Gyỏr.

Herczeg J. (1993) Külfơldi érdekeltségú cégek stratégiảja és managementje. Gazdaság és Társadalom, 6. 3855. 0 .

Iván L. (1993) Külföldi tőkeérdekeltségủ vegyes vállalatok létesítésének teruleti vonatkozásai Magyarországon. Földrajzi Értesitó, 1-4. 67-78. o.

Klekner P. (1990) Vegyes vállalatok magyarországi terjedése - Tényfeltáró gyorsértékelés. OT TGI, Budapest, 680.

Külföldi részvételü társaságok Magyarországon 1990., 1991.,1992. Magazin Kiadó, Budapest 1993.

Külföldi részvételú vegyes vállalatok Magyarországon. A Magyar Gazdasági Kamara Kiadványa, Budapest, 1991.2910.

Meskó A. (összeáll.) (1994) Külföldi mủködö tỏke Magyarországon 1992-ben. KSH, Budapest.

Páll Gy. (1993) Külföldi érdekeltségũ vállalatok Györ-Moson-Sopron megye gazdaságában. Tanulmányok, Elemzések, Dokumentumok, Javaslatok. MTA RKK ÉDO, Győr.

Rechnitzer J.-Sipák T. (szerk.) (1993) Az önkormányzatok szerepe és lehetösége a regionális ipari fejlesztés politikák kidolgozásában, megvalósitásában. MTA RKK ÉDO (Kézirat) Györ.

Szücs L.-né. (1993) A külföldi érdekeltségủ vállalkozások alakulása Nógrád megyében 1991-ben. Településfejlesztés, 1. 47-49. o.

Tájékoztató - A makrogazdasági folyamatok alakulása a regionális adatok tưkrében. 1992. IKM Foglalkozáspolitikai Főosztály (Kézirat) Budapest. 


\section{THE ROLE AND SPATIAL SPREADING OF FOREIGN CAPITAL IN HUNGARY}

\section{GÁBOR NAGY}

The direct inward investments mean one of the most important chances for Hungary for an economic catching up. The incoming capital is not of credit type, it stimulates home investments. The implementation of the specific projects may have employment consequences touching whole regions. They may bring novelties for the Hungarian units usually all in technical, technological, management, marketing, monitoring and quality respects, bringing developed Western productive and sales methods close at hand.

Combining these with the Hungarian characteristics, the productivity of the Hungarian economic sectors can be raised to a higher level. Such a form of economic co-operation can open the Eastern and Western markets for home-made products, increasing the possibilities for export.

The appearance of the direct inward investments can provide a chance for a region for catching up, so in the study we focused mainly on the spatial distribution, penetration of the capital both in space and settlement hierarchy.

In our work we were the first to attempt to divide the past period of time into sections by the behaviour of the foreign capital.

We examined, by these sections, the changes taking place in the sectoral distribution of the joint ventures, the transitions that could be registered in the decision on the corporate form.

We examined the origin of the incoming capital by country of origin, within this we tried to highlight the settlement preferences of the specific investing countries within Hungary.

We tried to follow the change in the rate of foreign capital in the founded joint ventures during the whole period, within this we paid special attention to the $100 \%$ foreign owned or foreign majority businesses.

The most significant part of the study tried to trace several dimensions of the spatial spreading of the joint ventures. Partly we were seeking the differences at the level of the big regions and counties, partly we tried to make a distinction between the capacities of the levels of the settlement hierarchy. During the work, on the one hand, we categorised regions, counties and small regions with similar development patterns, on the other hand, we delimited the active and passive regions within Hungary (partly irrespective of counties and regions) and tried to introduce the investment types, behaviours typical of the region.

In the last part we tried to show the chances for the regional policy in improving the conditions for the reception and functioning, of the foreign capital. We came to the conclusion that state participation is still inevitable in the formation or alteration of the images of some regions. 